\title{
Effects of Continuous Cropping of Sweet Potatoes on the Bacterial Community Structure in Rhizospheric Soil
}

\section{Zhiyuan Gao}

Institute of Cereal and Oil Crops, Hebei Academy of Agriculture and Forestry Sciences

\section{Yaya Hu}

Institute of Cereal and Oil Crops, Hebei Academy of Agriculture and Forestry Sciences, The key Laboratory of Crop Genetics and Breeding of Hebei

\section{Meikun Han}

Institute of Cereal and Oil Crops, Hebei Academy of Agriculture and Forestry Sciences, The key Laboratory of Crop Genetics and Breeding of Hebei

\section{Junjie Xu}

Institute of Cereal and Oil Crops, Hebei Academy of Agriculture and Forestry Sciences, The key Laboratory of Crop Genetics and Breeding of Hebei

\section{Xue Wang}

Agricultural Product Quality Inspection Center of Shijiazhuang

\section{Lanfu Liu}

Institute of Cereal and Oil Crop Genetics and Breeding of Hebei

\section{Zhonghou Tang}

Xuzhou Sweet Potato Research Center, Xuzhou Institute of Agricultural Sciences

\section{Weijing Jiao}

Institute of Cereal and Oil Crops, Hebei Academy of Agriculture and Forestry Sciences, The key Laboratory of Crop Genetics and Breeding of Hebei

\section{Rong Jin}

Xuzhou Sweet Potato Research Center, Xuzhou Institute of Agricultural Sciences

\section{Ming Liu}

Xuzhou Sweet Potato Research Center, Xuzhou Institute of Agricultural Sciences

\section{Zhengjun Guan}

Department of Life Science,Yuncheng University

\section{Zhimin Ma ( $\nabla 13785181259 @ 163 . c o m)$}

Institute of Cereal and Oil Crops, Hebei Academy of Agriculture and Forestry Sciences

\section{Research article}


Keywords: Bacterial community, continuous cropping, rhizospheric soil, sweet potato

Posted Date: December 11th, 2020

DOI: https://doi.org/10.21203/rs.3.rs-61006/v3

License: (c) (1) This work is licensed under a Creative Commons Attribution 4.0 International License. Read Full License

Version of Record: A version of this preprint was published at BMC Microbiology on April 1st, 2021. See the published version at https://doi.org/10.1186/s12866-021-02120-6. 


\section{Abstract}

Background: Continuous cropping obstacles from sweet potatoes are widespread, which seriously reduce the yield and quality, causing certain economic losses. Bacteria of rhizospheric soil are the richest and are associated with obstacles to continuous cropping. However, few studies have examined how continuous sweet potato cropping affects the rhizospheric soil bacterial community structure.

Results: In the study, the Illumina MiSeq method was used to explore the variations in

rhizospheric soil bacterial community structure of different sweet potato varieties after continuous cropping, as well as the correlation between soil characteristics and the bacterial community. The results showed that (1) the dominant bacterial phyla in rhizospheric soils from both Xushu 18 and Yizi 138 were Proteobacteria, Acidobacteria, and Actinobacteria. The most dominant genus was Subgroup 6_norank. The relative abundance of rhizospheric soil bacteria varied significantly between the two sweet potato varieties. (2) The richness and diversity indexes of bacteria were higher in Xushu 18 rhizospheric soil than in Yizi 138 soil after continuous cropping. Moreover, beneficial Lysobacterand Bacillus were more prevalent in Xushu 18, while Yizi 138 contained more harmful Gemmatimonadetes. (3) Soil pH decreased after continuous cropping, and redundancy analysis indicated that soil pH was significantly correlated with the bacterial community. Spearman's rank correlation coefficient analysis demonstrated that pH was positively associated with Planctomycetes and Acidobacteria, but negatively associated with Actinobacteria and Firmicutes.

Conclusions: After continuous cropping, the bacterial community structure and physicochemical properties of sweet potato rhizospheric soil were changed, and the changes from different sweet potato varieties were different. The contents of Lysobacter and Bacillus were higher in the sweet potato variety resistant to continuous cropping. It provides a basis for developing new microbial fertilizers for sweet potatoes to alleviate the continuous cropping obstacle.

\section{Background}

Sweet potato [/pomoea batatas (L.) Lam.] is a major food crop that is cultivated worldwide. It is a highyield, highly efficient, and strongly adaptable crop that is resistant to drought and barrenness [1-3]. In addition, sweet potato is rich in nutrients and has cancer preventing properties, making it increasingly popular [4]. Therefore, sweet potato planting areas increase annually. In China, because of limited cultivatable land, sweet potatoes are grown continuously in the same fields. However, continuous cropping can lead to decreased yield and quality, severe plant death, and a decreased or non-existent harvest [5-6]. In recent years, the phenomenon of sweet potato continuous cropping obstacles has become serious, and it has huge adverse impact on the sweet potato industry [7].

Continuous cropping obstacles have a certain relationship with soil enzyme activity, soil microbial community, and root exudates [8-10 ]. Soil microorganisms are the key factors related to changes in soil quality, fertility, and productivity [11-13]. The rhizosphere is the soil region near the plant roots, where 
interactions between soil microorganisms and plant root systems are very strong [14,15]. Rhizospheric soil microorganisms are closely related to the absorption and transformation of soil nutrients. Therefore, their community structure is a major factor affecting plant growth, development, and health [16-19]. Many reports have indicated that continuous cropping changes the structure of rhizospheric soil microbes [2023]. These changes have further led to severe continuous cropping obstacles [9]. Therefore, the relationship between continuous cropping and the soil microorganisms has become a research hotspot [7].

Bacteria are the most abundant in rhizospheric soil and are the important component [24 25]. Increasing reports have noted that continuous cropping causes changes in rhizospheric soil bacterial community structure. Previous studies on konjac and vanilla revealed that continuous cropping changed bacterial communities, resulting in a decrease of beneficial bacteria and an increase of harmful bacteria[26-27]. Moreover, the study found that the bacteria decreased after Panax notoginseng continuous cropping for 3 years. And the rhizospheric soil bacterial diversity of the healthy Panax notoginseng was greater than that of diseased strains. Canonical correspondence analysis found that $\mathrm{P}, \mathrm{pH}$, and soil organic matter had the greatest impacts on the bacterial community [28]. Furthermore, $\mathrm{Na}$ et al. [29] and Lei et al [30] revealed that the number of bacterial species and the a-diversities of the rhizospheric soil bacterial communities of Lycium barbarum L. and Sophora flavescens decreased significantly after continuous cropping.

The detrimental effects of continuous cropping on microbial community structures in rhizospheric soil have been demonstrated for a variety of different crops. However, studies focusing on the continuous cropping of sweet potatoes have mainly focused on the prevention and treatment of pests and diseases [31]. Accordingly, little is known about how this process affects the bacterial community structure and the physical and chemical properties (especially the medium and micro elements) in the rhizospheric soil of sweet potato. Various medium and micro elements are not only indispensable components of plants, but also participate in various metabolic reactions and act as catalysts for various enzymes [32]. Moreover, it remains unclear whether there are differences in the bacterial community structure of rhizospheric soil after the continuous cropping of different sweet potato cultivars. For the first time, we have used two sweet potato varieties and high-throughput techniques to study bacterial community structure changes of rhizospheric soil after continuous cropping, and analyzed correlations between soil characteristics and bacterial community changes after continuous cropping. It aimed to reveals how continuous cropping affects the rhizosphere soil bacterial community structures of two sweet potato varieties, and to provide insights into the application of biological control the continuous cropping obstacles of sweet potatoes.

\section{Results}

\section{Physicochemical properties of sweet potato rhizospheric soil}

Available Mn in the Xushu 18 (X18) and Yizi 138 (Y138) rhizospheric soils decreased by $32.68 \%$ and $31.14 \%$, respectively, at the beginning of planting in 2016 than in 2015 , and by $27.35 \%$ and $31.10 \%$ in the 
pre-harvest period (Table 1). The soil pH of the $\mathrm{X} 18$ and $\mathrm{Y} 138$ were decreased by $2.72 \%$ and $3.11 \%$, respectively, at the beginning of planting in 2016 than in 2015; change in pH were not significant in the pre-harvest period. At the beginning of planting, available Ca in the X18 and Y138 rhizospheric soils increased by $29.80 \%$ and $38.97 \%$, respectively; available $\mathrm{Zn}$ increased by $56.11 \%$ and $43.19 \%$, respectively in 2016 than in 2015 . And available Ca increased by $30.75 \%$ and $26.47 \%$, respectively, while available $\mathrm{Zn}$ increased by $29.46 \%$ and $30.81 \%$, respectively, in the pre-harvest period in 2016 than in 2015 . Available Fe in the $\mathrm{X} 18$ and $\mathrm{Y} 138$ soils decreased by $18.61 \%$ and $17.08 \%$, respectively, in the pre-harvest period in 2016 than in 2015 , but was not significantly different at the beginning of planting. Available B in the X18 rhizospheric soil decreased by $20.63 \%$ at the beginning of planting, while the change in the $Y 138$ soil was not significant.

\section{Rhizospheric soil bacterial a-diversity}

The average coverage of all samples was $96.19 \%$ (Table 2). Rarefaction curves were close to plateau (Fig. 1), indicating that our sequencing depth was good. The reads ranged from 24,695-37,688 for samples, and the operational taxonomic units (OTUs) ranged from 3,137-3,734. Chao, Shannon, and Simpson indexes were computed based on the bacterial OTUs. Unlike the Shannon index, the larger the Simpson value, the lower the community diversity. The Chao and Shannon values of the X18 and Y138 soils were higher in the pre-harvest period than at the beginning of planting, while the opposite was true of the Simpson index, indicating that two communities had higher species richness and diversity in the pre-harvest period.

After X18 continuous cropping, the Chao index decreased by $2.53 \%$ and the Shannon and Simpson indices were basically unchanged at the beginning of planting in 2016 than in 2015; in the pre-harvest period, the Chao and Shannon indices increased by $5.95 \%$ and $1.59 \%$, respectively, and the Simpson index decreased by $17.86 \%$. After Y138 continuous cropping, the Chao and Shannon indices increased by $2.80 \%$ and $1.66 \%$, respectively, and the Simpson indices decreased by $22.22 \%$ at the beginning of planting in 2016 than in 2015; in the pre-harvest period, the Chao and Shannon indices increased by $2.53 \%$ and $1.16 \%$, respectively, and the Simpson index decreased by $14.29 \%$. These indicated that the diversity and richness of rhizosphere soil bacteria of X18 and Y138 also increased after continuous cropping.

X18 had higher Chao and Shannon indices than Y138, which were contrary to the Simpson index. In other words, the bacterial richness and diversity were higher in X18 rhizospheric soil than in Y138 soil.

\section{Community composition analysis of rhizospheric soil bacteria}

At the phylum level (Fig. 2), the dominant bacterial phyla of all samples were Proteobacteria $(28.5 \%-$ $34.9 \%)$, Acidobacteria (10.4\%-21.1\%), Actinobacteria (11.3\%-18.1\%), Planctomycetes $(5.2 \%-9.9 \%)$, Chloroflexi (4.6\%-9.1\%), Bacteroidetes (3.4\%-6.1\%), Gemmatimonadetes (3.0\%-7.4\%), and Firmicutes $(1.4 \%-10.9 \%)$. Among them, Proteobacteria was the most abundant phylum, followed by Acidobacteria and Actinobacteria. 
After $\mathrm{X} 18$ and $\mathrm{Y} 138$ continuous cropping, Proteobacteria decreased by $17.30 \%$ and $8.05 \%$, respectively, in the pre-harvest period. Acidobacteria showed a decreasing trend and finally increased slightly, while Actinobacteria showed the opposite trend. After continuous cropping, the Firmicutes content of X18 soil increased by $71.54 \%$ and $97.66 \%$ in the early planting and early harvest stages, respectively, and by $4.10 \%$ and $129.57 \%$, respectively in Y138 soil. Moreover, In both varieties, the Firmicutes contents was higher at the beginning of planting than in the early harvest period of the same year. However, the opposite trend was observed for Planctomycetes. The Planctomycetes content of X18 in the early planting and early harvest stages decreased by $30.36 \%$ and $7.35 \%$, respectively, while that of $\mathrm{Y} 138$ decreased by $40.51 \%$ and $19.04 \%$, respectively. Further, the Chloroflexi and Gemmatimonadetes contents showed increasing trends. In X18 and Y138 rhizospheric soils, Chloroflexi increased by $81.09 \%$ and $96.69 \%$, respectively ,and Gemmatimonadetes increased by $103.11 \%$ and $122.56 \%$, respectively. Gemmatimonadetes was higher in Y138 rhizospheric soil than in X18 soil, especially in 2016.

At the genus level (Fig. 3), Subgroup 6_norank (6.59\% - 14.74\%), Nitrosomonadaceae_uncultured $(1.83 \%-6.40 \%)$, and Anaerolineaceae_uncultured (1.75\%-3.63\%) were the top three dominant bacteria genera in all rhizospheric soils of $\mathrm{X} 18$ and $\mathrm{Y} 138$. Other major genera were Bacillus $(0.65 \%-4.14 \%)$, MSB1E8_norank $(0.87 \%-3.83 \%)$, Tepidisphaeraceae_norank $(1.71 \%-2.56 \%)$, Xanthomonadales_norank $(0.62 \%-2.08 \%)$, and Lysobacter $(0.55 \%-2.06 \%)$. After two years of continuous cropping, Subgroup 6_norank displayed decreasing trends in the X18 and $\mathrm{Y} 138$ rhizospheric soils, decreasing by $54.34 \%$ and $52.66 \%$, respectively, and then increased slightly in the 2016 pre-harvest period. However, Nitrosomonadaceae-uncultured and Anaerolineaceae-uncultured were present at low levels at the beginning of planting, then were increased in the pre-harvest period of the same year. Bacillus and Lysobacter showed the opposite trend. Moreover, in every sampling period, Lysobacter was higher in the rhizospheric soil of X18 than in that of Y138. This was also true of Bacillus, except for the beginning of planting in 2015. Furthermore, in2016, the reduction of Lysobacter in X18 and Y138 rhizosphere soil was 1.3 and 2.4 times greater than in 2015 .

\section{Venn analysis of rhizospheric soil bacteria}

Venn diagram revealed the overlapped and unique OTUs of all samples (Fig. 4). After two years of continuous cropping, the OTUs shared by all samples was 507 . In the four sampling periods, there were $95,158,127$, and 202 unique OTUs in the rhizospheric soils of $X 18$, and 89, 124,141, and 159 unique OTUs in the rhizospheric soils of Y138. As continuous cropping year increased, the specific OTUs in X18 soil increased by $33.68 \%$ and $27.85 \%$ in the early planting and early harvest periods, while the OTUs in Y138 soil increased by $58.43 \%$ and $28.23 \%$ in these periods.

The number of OTUs specific to X18 was greater than that specific to Y138 (except for the beginning of planting in 2016), indicating that continuous cropping led to changes in the bacterial communities in X18 and Y138 rhizosphere soil. These differences were largest during the early harvest period of 2016.

\section{Heatmap, clustering, and principal component analysis (PCA) of rhizospheric soil bacteria}


The results of heatmap and clustering analysis of 40 phyla in all samples are illustrated in Fig. 5, and clearly demonstrate the differences in rhizospheric soil bacterial composition between the X18 and Y138 varieties. The samples grouped into two clusters and samples from the same consecutive cropping times clustered together. In addition, $\mathrm{X} 18$ and $\mathrm{Y} 138$ samples from the same sampling periods grouped together.

The OTUs of X18 and Y138 were subjected to PCA. The extracted two principal components explained $72.48 \%$ of the total variation (Fig. 6). As continuous cropping time increased, samples from different sampling times became farther apart. However, at the same sampling times, $\mathrm{X} 18$ and $\mathrm{Y} 138$ samples were relatively close to each other. With continuous cropping, the distance between these samples also gradually increased, which indicated that differences between their bacterial communities were also increasing. These results were consistent with the results of the heatmap and cluster analyses in Fig. $\mathbf{5}$. Overall, the results suggested that (i) continuous cropping led to bacterial community structure changes in X18 and Y138 rhizosphere soil; (ii) rhizospheric soil bacterial community structures of $\mathrm{X} 18$ and $\mathrm{Y} 138$ were similar in the same sampling period.

\section{Relationship between bacterial phyla and physicochemical characteristics of sweet potato rhizospheric soil}

The results of redundancy analysis (RDA) on top ten bacterial phyla and environmental factors of X18 and $\mathrm{Y} 138$ rhizospheric soil are showed in Fig. 7. RDA1 and RDA2 explained $56.57 \%$ and $28.05 \%$ of the total variation, respectively. The magnitude of the effects of soil properties on bacterial community structure had the following order, soil $\mathrm{pH}>\mathrm{Ca}>\mathrm{Mn}>\mathrm{Zn}>\mathrm{B}>\mathrm{Fe}$. The results showed that soil $\mathrm{pH}$ $\left(r^{2}=0.9737, \operatorname{Pr}=0.004\right)$ and available $\mathrm{Ca}\left(r^{2}=0.8815, \mathrm{Pr}=0.011\right)$ were significantly correlated with the bacterial community. It indicated that $\mathrm{pH}$ was a strong predictor of the $\mathrm{X} 18$ and $\mathrm{Y} 138$ rhizospheric soil bacterial community compositions.

In addition, the results of Spearman's correlation coefficient analysis were as follows (Fig. 8). pH was positively correlated with Planctomycetes $(R=0.97)$ and Acidobacteria $(R=0.93)$, but had negative correlations with Actinobacteria $(R=-0.79)$ and Firmicutes $(R=-0.72)$; available Ca was positively related to Actinobacteria $(R=0.89)$ and Gemmatimonadetes $(R=0.86)$, and was inversely correlated with Acidobacteria $(R=-0.79)$, Planctomycetes $(R=-0.75)$, and Nitrospirae $(R=-0.72)$. At the same time, it can be seen from Fig. 8 that the soil physicochemical properties were divided into two groups, with available $\mathrm{Ca}$ and available $\mathrm{Zn}$ clustered into one group and the rest clustered into another, indicating that available $\mathrm{Ca}$ and available $\mathrm{Zn}$ had similar effects on the bacteria, which were different from the rest.

\section{Discussion}

To obtain a more comprehensive understanding of the rhizospheric soil bacterial community structure of sweet potatoes, the Illumina MiSeq method was used in this study [33-34]. The V4-V5 highly variable region was selected as the sequencing region because a previous study demonstrated that this region was the best sequencing region among nine highly-variable regions [35]. 
We found that the Shannon index increased with continuous cropping, indicating an increase in bacterial diversity in the rhizospheric soil. This was aligned with previous studies on Andrographis paniculata and potatoes [36-37], but contrary to Sophora flavescens and Lycium barbarum L. under continuous cropping conditions [29-30]. The differences may be due to variations in the duration of continuous cropping, soil environmental conditions, plant types, etc.

The most dominant bacterial phylum in the $\mathrm{X} 18$ and $\mathrm{Y} 138$ rhizospheric soil was Proteobacteria, which was in accordance with published reports $[8,24,36,38]$. The main function of Proteobacteria is to decompose organic matter and promote plant growth [39-40]. The most dominant genus was Subgroup 6_norank, which accorded with Yin et al. [24]. As continuous cropping time increased, the Proteobacteria content decreased, which was in agreement with Liu et al. [41], while was inconsistent with the report on A. paniculata [36]. Acidobacteria showed a tendency to decrease gradually and then increase slightly. Actinobacteria tended to increase gradually and then decrease slightly, which was almost consistent with Yin et al. [24] and our previous study [42], but differed from the results of Li et al. [8] and Wu et al. [27]. These discrepancies might be due to differences in plant species, plant genotypes, continuous cropping durations, and soil types, which also cause different changes in soil microorganisms [14, 43-45].

We also found that some microbial changes were affected by the sweet potato growth stage. For instance, the content of Firmicutes was high at the beginning of planting and decreased in pre-harvest period. This indicates that the growth of sweet potato has a certain influence on it. After the sweet potatoes were harvested, its content recovered. These changes may also be related to the season. Li et al. [46] found that seasonal changes have important impacts on soil microbes, but that different microbes vary with season differently.

As continuous cropping time increased, the content of Lysobacter decreased. It is well known that Lysobacter is an important biocontrol bacteria with strong bacteriolytic and bacteriostatic effects [47]. For example, Lysobacter enzymogenes $\mathrm{OH} 11$ was found to exert a significant bacteriostatic effect on sweet potato soft rot pathogen . Conversely, Gemmatimonadetes, a harmful bacteria that can lead to $\mathrm{N}$ loss and reduce crop growth [40], increased with continuous cropping.

Sweet potato continuous cropping changed the bacterial community structure, which was aligned with previous reports [8,26-27]. These changes further increased the continuous cropping obstacles of X18 and Y138. The average yields of the two varieties both decreased, $X 18$ decreased from 12.36 to $10.64 t$ $\mathrm{hm}^{-2}$, and $\mathrm{Y} 138$ decreased from 9.15 to $2.66 \mathrm{t} \mathrm{hm}^{-2}$.

Consequently, maintaining a balance of bacterial community structure is very important for prevention and control continuous cropping obstacles. In practice, microbial fertilizers and soil modifiers [48-50] can be applied to maintain the microecological balance.

We observed differences in rhizospheric soil bacterial community composition between the two sweet potato varieties after continuous cropping. The number of OTUs specific to X18 increased more than those specific to Y138, and the community structures became increasingly different. According to a- 
diversity analysis, the rhizospheric soil of X18 had higher bacterial richness and diversity. Thus, the community structure of X18 was relatively stable, its tolerance to soil environmental changes was greater, and its resistance to continuous cropping obstacles was stronger, while the community structure of Y138 was more susceptible to continuous cropping. Moreover, Lysobacter and Bacillus were higher in the X18 rhizosphere soil than in the Y138 soil. Many studies have shown that Bacillus may resist some soilborne diseases [14,27,40]. Higher Lysobacter and Bacillus contents would therefore be more conducive to the growth of $X 18$. In contrast, the rhizospheric soil of Y138 contained more harmful Gemmatimonadetes. Therefore, it is also important to choose varieties of sweet potato that are resistant to continuous cropping in production practice.

After sweet potato continuous cropping, rhizospheric soil physicochemical properties were also changed. Moreover, it was found that $\mathrm{pH}$ had the greatest impact on the bacterial community structure, which was consistent with several published reports [8,51,52]. Soil pH can affect soil microbial physiological metabolism, alter competitive relationships within microbial communities, and inhibit the growth of nonadapted microbes [29], all of which affect microbial community structure. In terms of the three bacteria phyla with the highest relative content, Acidobacteria was positively correlated with $\mathrm{pH}$, which was in line with Yang et al. [40]; Actinobacteria was negatively correlated with $\mathrm{pH}$, which was in agreement with previous studies [27, 53]. However, the results were different from those reported by Li et al. [8], which might have been due to difference in plant age or genotype [54].

Similar to bacteria, soil fungi are important decomposers. However, some fungi are strongly associated with plant diseases $[55,56]$. The results of our previous study indicated that fungal diversity and abundance in rhizospheric soil were significantly increased after continuous cropping. Furthermore, the contents of Fusarium, Verticillium, and Colletotrichum, the pathogens of sweet potatoes, were increased. These changes affected the balance of the fungal community structure [7].

Overall, after continuous cropping, the microbial community structure of sweet potato rhizospheric soil was changed, which might be a crucial aspect contributing to continuous cropping obstacles. Thus, maintaining the microecosystem balance of the rhizosphere soil is crucial to relieve the continuous cropping obstacles. In addition, continuous cropping obstacles are related to many factors. It is necessary to combine with many other methods to solve this problem. Therefore, we will perform further in-depth research on the mechanisms of sweet potatoes continuous cropping obstacles.

\section{Conclusions}

The continuous cropping of sweet potatoes obviously affected the bacterial community structure, physical and chemical properties of the rhizosphere soil. The bacterial diversity increased; however, the changes in the soils of two sweet potato varieties were different. The contents of Lysobacterand Bacillus were higher in the sweet potato variety that was resistant to continuous cropping. It provides a basis for the development of specialized microbial fertilizers for sweet potatoes. Therefore, further research is 
needed to see if $L y$ sobacter and Bacillus could be used to produce microbial fertilizers to mitigate continuous cropping obstacles of sweet potatoes.

\section{Methods}

\section{Study area and materials}

Our study was conducted at the Dishang test station of Institute of Cereal and Oil Grops, Hebei Academy of Agriculture and Forestry Sciences, China ( $\left.37^{\circ} 56^{\prime} 24.62^{\prime \prime} \mathrm{N}, 114^{\circ} 42^{\prime} 46.96^{\prime \prime} \mathrm{E}\right)$ [7]. There was a warm temperate sub - humid continental monsoon climate and the local soil type is Mottlic Hapli-Ustic Argosols (cinnamon soil). Two sweet potato varieties were used as experimental materials, one was X18 that was resistant to continuous cropping and the other was Y138 that was susceptible to continuous cropping. Both varieties were collected from the Institute of Cereal and Oil Crops, Hebei Academy of Agriculture and Forestry Sciences.

\section{Experimental design and sample collection}

Sweet potatoes were planted in May and harvested in October each year, and were continuously planted for 2 years (2015-2016). After each harvest, the fields were left fallow for the rest of the year. A random block design was used, with three experimental replicates. Details of the plot can be found in our previous report [7]. Agronomic management was the same for all fields over the two years. Rhizospheric soil was collected 30 days after planting and 7 days before the harvest, for a total of four sampling periods. Rhizospheric soil samples were taken by the method of Sun et al. [57]. For each sweet potato variety at each sampling point, the rhizospheric soils of 15 sweet potatoes located in an "S" shape were collected from each plot and mixed thoroughly to generate one composite soil sample. All samples were quickly taken to the laboratory in a cooler. Each sample was filtered through a 2-mm sieve, and then divided into two portions. One portion was stored at $-80^{\circ} \mathrm{C}$ for DNA analysis, the other portion was air-dried for soil characteristics analysis.

\section{Soil physicochemical property analysis}

Soil $\mathrm{pH}$ was determined by the electrode method (2.5:1 water: soil ratio)[40], and available $\mathrm{Ca}, \mathrm{B}, \mathrm{Fe}, \mathrm{Mn}$, and $\mathrm{Zn}$ were measured using the atomic absorption method according to Du and Gao [58].

\section{DNA extraction, amplification, and sequencing}

The DNA was extracted with an E.Z.N.A. ® Soil DNA Kit following the instructions. The V4-V5 regions were amplified by polymerase chain reaction (PCR) with 515F 5'-barcode-GTGCCAGCMGCCGCGG)-3' and 907R 5'-CCGTCAATTCMTTTRAGTTT-3', where barcode was an 8-base sequence unique to each sample. PCR reactions and amplicons extraction and purification were performed by the method of Yang et al. [40]. Purified PCR products were quantified using Qubit ${ }^{3} 3.0$, and every 24 amplicons with different barcodes were equally mixed. Illumina Pair-End library construction and sequencing were performed 
according to our previous report [7]. Complete data sets were deposited in the NCBI Sequence Read Archive database under accession number SRP214716.

\section{Processing and statistical analysis of sequencing data}

To remove low quality sequences, quality control and sequence quality filtering were applied according to Yang et al. [40]. OTUs were clustered with 97\% similarity cutoff with UPARSE (version 7.1 http://drive5.com/uparse/) and chimeric sequences were identified and removed with UCHIME. RDP Classifier was used to analyze the phylogenetic affiliations of each 16S rRNA gene sequence against the SILVA (http://www.arb-silva.de) database with a confidence threshold of 70\% [40].

Chao, Shannon, and Simpson indexes were calculated with Mothur v.1.21.1 [59]. PCA was performed with R-forge (the PCA graphics was generated with Vegan 2.0 package). Shared and unique OTUs were analyzed using Venn diagrams by VennDiagram. RDA was performed to analyze the correlations between environmental factors and bacterial community composition. Spearman's rank correlations coefficients and Heatmap figures were performed with Vegan packages in R. The data of the physicochemical properties of rhizospheric soil were analysed by one-way analysis of variance (ANOVA) $(P<0.05)$ in SPSS v21.0 [40].

\section{Declarations}

\section{Ethics approval and consent to participate}

Not applicable.

\section{Consent for publication}

Not applicable.

\section{Availability of data and materials}

All data generated or analysed during this study are included in this published article.

\section{Competing interests}

The authors declare that they have no competing interests.

\section{Funding}

This work was supported by the National Natural Science Foundation of China (grant number 31771731); The Modern Agriculture Industrial Technology System Innovation Team Project of Hebei Province (grant number HBCT2018080203); The Modern Agricultural Science and Technology Innovation Project of Hebei Province (grant number 2019-4-2-7); China Agriculture Research System (CARS-10-C1, Sweet potato) and the Natural Science Foundation of Hebei Province, China (grant number C2019301127). The 
funding bodies played no role in the design of the study or collection, analysis, and interpretation of data or in writing the manuscript.

\section{Authors' contributions}

ZM and ZJG designed this experiment. $L L$ and WJ performed samples collection. $Y H, J X, X W, Z T, R J$ and $M L$ executed the experiment. ZYG, MH and ZT analyzed the data. ZYG, YH and MH finished the manuscript. All authors read and approved the final manuscript.

\section{Acknowledgements}

We thank Prof. Xiumin Zhang from Hebei University and Prof. Shulong Chen from the Plant Protection Institute, Hebei Academy of Agricultural and Forestry Sciences for their help with our manuscript.

\section{Abbreviations}

X18:xushu18;Y138: Yizi138; OTUs: Operational taxonomic units ; PCA: Principal component analysis; RDA: Redundancy analysis; ANOVA: one-way analysis of variance.

\section{References}

1. Dai QW, Niu FX, Sun J, Cao J. Development and trend analysis of Sweetpotato processing industry in China. Agricultural Engineering Technology. 2015; 35: 27-31. doi:10.16815/j.cnki.115436/s.2015.35.003

2. Mateus JR, Marques JM, Dal' Rio I, Vollu RE, Coelho MRR, Seldin L. Response of the microbial community associated with sweet potato (Ipomoea batatas) to Bacillus safensis and Bacillus velezensis strains(Article). Antonie van Leeuwenhoek, International Journal of General and Molecular Microbiology. 2019;112:501-512. doi.org/10.1007/s10482-018-1181-y

3. Song CJ, Wang JC. Research progress on high yield of sweetpotato. Tillage and Cultivation. 2007;2: 45-47. doi:10.13605/j.cnki.52-1065/s.2007.02.027

4. Sheikha AFE, Ray RC. Potential impacts of bioprocessing of sweet potato: Review. Critical Reviews in Food Science and Nutrition. 2015;57: 455-471. doi:10.1080/10408398.2014.960909

5. Jia ZD, Xie YZ, Yin QH, Guo XD, Ji XQ. Study progress and perspective of black rot resistant germplasm in sweetpotato. Journal of Plant Genetic Resources. 2010;11: 424-427,432.

6. Zhou Z, Ma DF. Research status and prospect of sweetpotato stem nematode. Rain Fed Crops. 2003;23: 288-290.

7. Gao ZY, Han MK, Hu YY, Li ZQ, Liu CF, Wang X, et al. Effects of continuous cropping of sweet potato on the fungal community structure in rhizospheric soil. Frontiers in Microbiology. 2019;10:2269. doi: 10.3389/fmicb.2019.02269

8. Li H, Wang JQ, Liu Q, Zhou ZF, Chen F, Xiang D. Effects of consecutive monoculture of sweet potato on soil bacterial community as determined by pyrosequencing. Journal of Basic Microbiology. 
2019;59: 181-191. doi:10.1002/jobm.201800304

9. Sun CS. Study on the effects of Astragalus membranaceus (fisch.) bunge quality and rhizosphere soil microorganisms under continuous cropping with the Astragalus membranaceus (fisch.) bunge rotation mode. Dissertation, Inner Mongolia , Inner Mongolia university. 2017.

10. Huang WJ, Sun DL, Fu JT, Zhao HH, Wang RH, An YX. Effects of continuous sugar beet cropping on rhizospheric microbial communities. Genes. 2020;11:13. doi.org/10.3390/genes 11010013

11. Beckers B, Op De Beeck M, Weyens N, Boerjan W, Vangronsveld J. Structural variability and niche differentiation in the rhizosphere and endosphere bacterial microbiome of field-grown poplar trees. Microbiome. 2017;5: 25. doi: 10.1186/s40168-017-0241-2

12. Blagodatskaya E, Kuzyakov Y. Active microorganisms in soil: Critical review of estimation criteria and approaches. Soil Biology and Biochemistry. 2013;67: 192-211. doi:10.1016/j.soilbio.2013.08.024

13. Sun L, Gao JS, Huang T, Kendall JRA, Shen QR, Zhang RF. Parental material and cultivation determine soil bacterial community structure and fertility. FEMS Microbiology Ecology. 2015;91: 1-10. doi:10.1093/femsec/fiu010

14. Shang QH, Yang G, Wang Y, Wu XK, Zhao X, Hao HT, et al. Illumina-based analysis of the rhizosphere microbial communities associated with healthy and wilted Lanzhou lily (Lilium davidii var. unicolor) plants grown in the field. World Journal of Microbiology and Biotechnology 2016; 32:1-15. doi: 10.1007/s11274-016-2051-2

15. Li M, Yang FZ, Wu XY, Yan H, Liu Y. Effects of continuous cropping of sugar beet (Beta vulgaris L.) on its endophytic and soil bacterial community by high-throughput sequencing. Annals of Microbiology.2020;70:39. doi.org/10.1186/s13213-020-01583-8

16. Berendsen RL, Pieterse CMJ, Bakker PAHM. The rhizosphere microbiome and plant health. Trends in Plant Science. 2012;17:478-486. doi:10.1016/j.tplants.2012.04.001

17. Bron PA, Van BP, Kleerebezem M. Emerging molecular insights into the interaction between probiotics and the host intestinal mucosa. Nature Reviews Microbiology. 2012;10: 66-78. doi:10.1038/nrmicro2690

18. Fierer N, Lauber CL, Ramirez KS, Zaneveld J, Bradford MA, Knight R. Comparative metagenomic, phylogenetic and physiological analyses of soil microbial communities across nitrogen gradients. ISME Journal. 2012; 6: 1007- 1017. doi:10.1038/ismej.2011.159

19. Jin Z. The activities of the rhizosphere soil culturable microbial and soil nutrient under potato continuous and rotation system. Dissertation, Inner Mongolia: Inner Mongolia Agricultural University. 2012.

20. Guo LL, Yin WL, Guo DL, Hou XJ. Variations of bacterial biodiversity in rhizosphere soils of oil tree peony cropping continuously for different years. Scientia Silvae Sinicae. 2017;11:131-141. doi:10.11707/j.1001-7488.20171115

21. Huang LF, Song LX, Xia XJ, Mao WH, Shi K, Zhou YH, et al. Plantsoil feedbacks and soil sickness: from mechanisms to application in agriculture. Journal of Chemical Ecology. 2013;39: 232-242. 
doi:10.1007/s10886-013-0244-9

22. Qiao PL, Wu FZ, Zhou XG. Effects of continuous cropping on soil microbe communities and enzyme activity. Journal of Shenyang Agricultural University . 2013;5: 524-530. doi: 10.3969/j.issn.10001700.2013.05.003

23. Sun WQ, Kang YL, Liu JG, Jiang GY. Influence of continuous cropping of processing tomato on diversity of microflora in the rhizosphere soil. Acta Agriculturae Boreali-occidentalis Sinica. 2017;26:1099-1110. doi:10.7606/j.issn.1004-1389.2017.07.020

24. Yin JZ, Li L, Jie WG, Cai BY. Effect of continuous cropping on bacterial flora structure in soybean rhizosphere soil. Biotechnology Bulletin. 2018;34: 230-238. doi:10.13560/j.cnki.biotech.bull.1985.2017-0728

25. Tian WH, Yi XL, Liu SS, Zhou C, Wang AY. Effect of transgenic cotton continuous cropping on soil bacterial community. Annals of Microbiology. 2020;70:61. doi.org/10.1186/s13213-020-01602-8

26. Wu JP, Jiao ZB, Zhou J, Guo FL, Ding ZL, Qiu ZM. Analysis of bacterial communities in rhizosphere soil of continuously cropped healthy and diseased konjac. World Journal of Microbiology and Biotechnology. 2017;33:1-8. doi: 10.1007/s11274-017-2287-5

27. Wu X, Zhao QY, Zhao J, Xun WB, Li R, Zhang RF, et al. Different continuous cropping spans significantly affect microbial community membership and structure in a vanilla-grown soil as revealed by deep pyrosequencing. Microbial Ecology. 2015;70: 209-218. doi: 10.1007/s00248-0140516-0

28. Tan Y, Cui YS, Li HY, Kuang AX, Li XR, Wei YL, et al. Diversity and composition of rhizospheric soil and root endogenous bacteria in Panax notoginseng during continuous cropping practices. Journal of Basic Microbiology. 2017;57: 337-344. doi: 10.1002/jobm.201600464

29. Na XF, Zheng GQ, Xing ZC, Ma JP, Li ZH, Lu JH, et al. Effects of monocropping on diversity and structure of bacterial community in rhizosphere of replanted Lycium barbarum L. Acta Pedologica Sinica. 2017; 54:1280-1292. doi: 10.11766/trxb201702070036

30. Lei HY, Liu A, Hou QW, Zhao QS, Guo J, Wang ZJ. Diversity patterns of soil microbial communities in the Sophora flavescens rhizosphere in response to continuous monocropping. BMC Microbiology.2020;20:272. doi.org/10.1186/s12866-020-01956-8

31. Johnson AC, Gurr GM. Invertebrate pests and diseases of sweetpotato (Ipomoea batatas): a review and identification of research priorities for smallholder production. Annals of Applied Biology. 2016;168: 291-320. doi: 10.1111/aab.12265

32. Li ZG, Wang C, Yang JF, Zu Chao, Zheng WQ, Yu H. Characteristics analysis of soil and plant medium and micro element of consecutive cropping black pepper. Chinese Journal of Tropical Crops. 2017, 38: 2215-2220. doi: 10.3969/j.issn.1000-2561.2017.12.003 
33. Ai S, Zhang LJ, Xiao PY, Zhang XF, Xing ZL. Application and progress of high-throughput sequencing technology in the field of environmental microorganisms. Journal of Chongqing University of Technology (Natural Science). 2018;32:111 -121. doi: 10.3969/j.issn.1674-8425(z). 2018.09.018

34. Cheng YB, Ma QB, Ren HL, Xia QJ, Song EL, Tan ZY, et al. Fine mapping of a phytophthora-resistance gene RpsWY in soybean ( Glycine max L.) by high-throughput genome-wide sequencing. Theoretical and Applied Genetics. 2017; 130: 1041-1051. doi: 10.1007/s00122-017-2869-5

35. Sun DL, Jiang X, Wu QL, Zhou NY. Intragenomic heterogeneity of $16 \mathrm{~S}$ rRNA genes causes overestimation of prokaryotic diversity. Applied and environmental microbiology. 2013;79: 59625969. doi: 10.1128/aem.01282-13

36. Li JR, Chen XZ, Li SM, Zuo ZM, Zhan RT, He R. Variations of rhizospheric soil microbial communities in response to continuous Andrographis paniculata cropping practices. Botanical Studies. 2020;61:18. doi.org/ 10.1186/s 40529-020-00295-1

37. Zhao J, Zhang D, Yang YQ, Pan Y, Zhao DM, Zhu JH, et al. Dissecting the effect of continuous cropping of potato on soil bacterial communities as revealed by high-throughput sequencing. Plos One. 2020;15(5):e0233356. doi.org/10.1371/journal.pone.0233356

38. Zhu L, Zeng CL, Li YQ, Yu BQ, Gao F, Wei W, et al. The characteristic of bacterial community diversity in soybean field with continuous cropping based on the high-throughput sequencing. Soybean Science. 2017; 36:419-424. doi: 10. 11861 / j. issn. 1000-9841. 2017. 03. 0419

39. Li X, Sun ML, Zhang HH, Xu N, Sun GY. Use of mulberry-soybean intercropping in salt-alkali soil impacts the diversity of the soil bacterial community. Microbial Biotechnology. 2016;9: 293-304. doi: 10.1111/1751-7915.12342

40. Yang L, Tan LL, Zhang FH, Gale WJ, Cheng ZB, Sang W. Duration of continuous cropping with straw return affects the composition and structure of soil bacterial communities in cotton fields. Canadian Journal of microbiology. 2018;64: 167-181. doi: 10.1139/cjm-2017-0443

41. Liu X, Zhang JL, Gu TY, Zhang WM, Shen QR, Yin SX, et al. Microbial community diversities and taxa abundances in soils along a seven-year gradient of potato monoculture using high throughput pyrosequencing approach. PLoS One. 2014;9: e86610. doi: 10.1371/journal.pone.0086610

42. Gao ZY, Hu YY, Liu LF, Wang YN, Jiao WJ, Ma ZM, et al. Effects of continuous cropping on the microbial community structure of rhizospheric soil of sweetpotato. Journal of Nuclear. Agricultural. Sciences. 2019;6:1240-1247. doi: 10.11869/j.issn.100-8551.2019.06.1248

43. Zhao F, Zhao MZ, Wang Y, Pang FH. Biodiversity of bacteria and fungi in rhizosphere of strawberry with different continuous cropping years. Microbiology China. 2017;44: 1377-1386. doi:10.13344/j.microbiol.china.170170

44. Berg G, Smalla K. Plant species and soil type cooperatively shape the structure and function of microbial communities in the rhizosphere. FEMS Microbiology Ecology. 2009;68: 1-13. doi: 10.1111/j.1574-6941.2009.00654.x 
45. Liu F, Hewezi T ,Lebeis Sarah L, Pantalone V, Grewal Parwinder S, Staton Margaret E. Soil indigenous microbiome and plant genotypes cooperatively modify soybean rhizosphere microbiome assembly. BMC microbiology.2019;19(1):201. doi. 10.1186/s12866-019-1572-x

46. Li NJ, Zeng QP, He BH, Zhou F. Seasonal variations of soil microbial PLFAs and soil enzyme activity under the citrus plantation in Mt. Jinyun, Chongqing. Environmental Science. 2017;38:309 -317. doi:10.13227/j.hjkx.201605017

47. Chen ZH, Wang MZ, Chen BL, Huang JZ. The progress of research and application on Lysobacter and its bioactive compounds. Academic Periodical of Farm Products Processing. 2013;1: 5-10. doi; 10.3969/jissn.1671-9646(X).2013.01.002

48. Cai Y, Hao MD, Zang YF, He XY, Zhang LQ. Effect of long-term fertilization on microbial diversity of black loessial soil based on 454 sequencing technology. Journal of Nuclear Agricultural Sciences. 2015; 29:0344-0350. doi: 10.11869/j.issn.100-8551. 2015.02. 0344

49. Qiao XR. Effect of different amendments on soil microbial ecology. Dissertation, Zhejiang, Zhejiang University. 2011.

50. Tao L, Chu GX, Liu T, Tang C, Li JH, Liang YC. Impacts of organic manure partial substitution for chemical fertilizer on cotton yield, soil microbial community and enzyme activities in mono-cropping system in drip irrigation condition. Acta Ecologica Sinica. 2014;34: 6137-6146. doi: 10.5846 / stxb201301290184

51. Fernández-Calviño D, Bååth E. Growth response of the bacterial community to $\mathrm{pH}$ in soils differing in pH. FEMS Microbiology Ecology. 2010;73: 149-156. doi:10.1111/j.1574-6941.2010.00873.x

52. Qiao SS, Zhou YN, Liu JX, Jing JH, Jia T, Li C, et al. Characteristics of soil bacterial community structure in coniferous forests of Guandi Mountains, Shanxi Province. Scientia Silvae Sinicae . 2017;53:89-99. doi: 10.11707/j.1001-7488.20170211

53. Alami MM, Xue J, Ma Y, Zhu D, Gong Z, Shu S, et al. Structure, diversity, and composition of bacterial communities in rhizospheric soil of coptis chinensis franch under continuously cropped fields. Diversity. 2020;12: 57. doi: 10.3390/d12020057

54. Marques JM, da Silva TF, Vollu RE, Blank AF, Ding GC, Seldin L, Smalla K. Plant age and genotype affect the bacterial community composition in the tuber rhizosphere of field-grown sweet potato plants. FEMS microbiology ecology. 2014; 88(2):424-435. doi:10.1111/1574-6941.12313

55. Dong LL, Xu J, Feng GQ, Li XW, Chen SL. Soil bacterial and fungal community dynamics in relation to Panax notoginseng death rate in a continuous cropping system. Scientific Reports. 2016;6: 31802. doi: $10.1038 /$ srep31802

56. Shang HS. Modern immunology of plants. Beijing: China Agriculture Press. 2013.

57. Sun JZ, Xue QH, Tang M, Cao SM, Xing SL. Study on the effect of actinomycetes on microflora of replanted strawberry's root domain and the bio-control effectiveness. Journal of Northwest A\& $F$ University (Nat. Sci. Ed.). 2009;37: 153-158. doi:10.13207/j.cnki.jnwafu.2009.12.021 
58. Du S, Gao XZ. Soil analysis technical specification, 2nd Edition. Beijing: China. Agriculture Press. 2006.

59. Schloss PD, Westcott SL, Ryabin T, Hall JR, Hartmann M, Hollister EB, et al. Introducing mothur: opensource, platform-independent, community-supported software for describing and comparing microbial communities. Applied and Environmental Microbiology. 2009;75:7537 -7541. doi: 10.1128/aem.01541-09

\section{Tables}

Table 1. The physicochemical properties of different soil samples

\begin{tabular}{|c|c|c|c|c|}
\hline Sample & $\begin{array}{l}\mathrm{eCa} \\
\left(\mathrm{g} \mathrm{kg}^{-1}\right)\end{array}$ & $\begin{array}{l}\text { B } \\
\left(\mathrm{mg} \mathrm{kg}^{-1}\right)\end{array}$ & $\begin{array}{l}\mathrm{Fe} \\
\left(\mathrm{mg} \mathrm{kg}^{-1}\right)\end{array}$ & $\begin{array}{lll}\mathrm{Mn} & \mathrm{Zn} & \mathrm{pH} \\
\left(\mathrm{mg} \mathrm{kg}^{-1}\right) & \left(\mathrm{mg} \mathrm{kg}^{-1}\right)\end{array}$ \\
\hline x18-1 & $0.34 \pm 0.01 \mathrm{c}$ & $0.77 \pm 0.07 a$ & $4.64 \pm 0.67 c$ & $2.60 \pm 0.28 \mathrm{a} 1.65 \pm 0.13 \mathrm{~d} 8.57 \pm 0.06 \mathrm{a}$ \\
\hline x18-2 & $0.35 \pm 0.01 \mathrm{c}$ & $0.71 \pm 0.08 \mathrm{a}$ & b5.86 $\pm 0.30 a$ & $2.54 \pm 0.06 \mathrm{a} 1.96 \pm 0.01 \mathrm{c} 8.60 \pm 0.00 \mathrm{a}$ \\
\hline x18-3 & $0.45 \pm 0.01 b$ & $0.61 \pm 0.06 b$ & $4.78 \pm 0.16 \mathrm{bc}$ & $c 1.75 \pm 0.07 b 2.58 \pm 0.09 a 8.33 \pm 0.06 b$ \\
\hline$x 18-4$ & $0.45 \pm 0.00 \mathrm{ab}$ & b0.63 $\pm 0.05 b$ & $4.77 \pm 0.01 b c$ & $c 1.85 \pm 0.05 b 2.54 \pm 0.02 a 8.50 \pm 0.10 a$ \\
\hline Y138-1 & $0.34 \pm 0.02 \mathrm{c}$ & $0.78 \pm 0.05 a$ & $4.52 \pm 0.24 \mathrm{c}$ & $2.56 \pm 0.01 \mathrm{a} 1.73 \pm 0.06 \mathrm{~d} 8.57 \pm 0.06 \mathrm{a}$ \\
\hline Y138-2 & $0.36 \pm 0.01 \mathrm{c}$ & $0.69 \pm 0.04 \mathrm{ab}$ & b5.31 $\pm 0.53 \mathrm{al}$ & $\mathrm{b} 2.71 \pm 0.26 \mathrm{a} 1.66 \pm 0.17 \mathrm{~d} 8.60 \pm 0.00 \mathrm{a}$ \\
\hline Y138-3 & $0.47 \pm 0.02 a$ & $0.69 \pm 0.08 \mathrm{ab}$ & $b 4.70 \pm 0.18 b$ & $c 1.76 \pm 0.12 b 2.48 \pm 0.00 a 8.30 \pm 0.00 b$ \\
\hline Y138 & & & & 1 \\
\hline
\end{tabular}

Table 2. MiSeq sequencing results and a-diversity index of sweet potato rhizospheric soil samples 


\begin{tabular}{|c|c|c|c|}
\hline \multicolumn{4}{|c|}{ Sample ID Reads 0.97} \\
\hline & OTU Chao & CoverageShannon & Simpson \\
\hline X18-1 & \multicolumn{2}{|c|}{$(4440,4842)$} & $\begin{array}{l}0.0033 \\
(0.0032,0.0034)\end{array}$ \\
\hline$x 18-2$ & $\begin{array}{r}2804734054955 \\
(4743\end{array}$ & $\begin{array}{l}0.9543276 .91 \\
1) \quad(6.89,6.9\end{array}$ & $\begin{array}{l}0.0028 \\
(0.0027,0.0029)\end{array}$ \\
\hline$x 18-3$ & $\begin{array}{r}3542232074509 \\
(4324\end{array}$ & $\begin{array}{l}0.9671396 .67 \\
4) \quad(6.65,6.6\end{array}$ & $\begin{array}{l}0.0034 \\
(0.0033,0.0035)\end{array}$ \\
\hline$x 18-4$ & \multicolumn{2}{|c|}{$(5046,5485) \quad(7.01,7$} & $\begin{array}{l}0.0023 \\
(0.0022,0.0023)\end{array}$ \\
\hline Y138-1 & \multicolumn{2}{|c|}{$(4209,4596) \quad(6.62,6$} & $\begin{array}{l}0.0036 \\
(0.0035,0.0037)\end{array}$ \\
\hline Y138-2 & $\begin{array}{r}2469532304808 \\
(4590\end{array}$ & $(4590,5061)$ & $\begin{array}{l}0.0028 \\
(0.0027,0.0029)\end{array}$ \\
\hline Y138-3 & \multicolumn{2}{|c|}{$(4316,4739)$} & $\begin{array}{l}0.0028 \\
(0.0028,0.0029)\end{array}$ \\
\hline Y138-4 & $\begin{array}{r}3343636025074 \\
(4873\end{array}$ & $\begin{array}{l}0.9618976 .97 \\
\quad(6.95,6 .\end{array}$ & $\begin{array}{l}0.0024 \\
(0.0024,0.0025)\end{array}$ \\
\hline
\end{tabular}

\section{Figures}




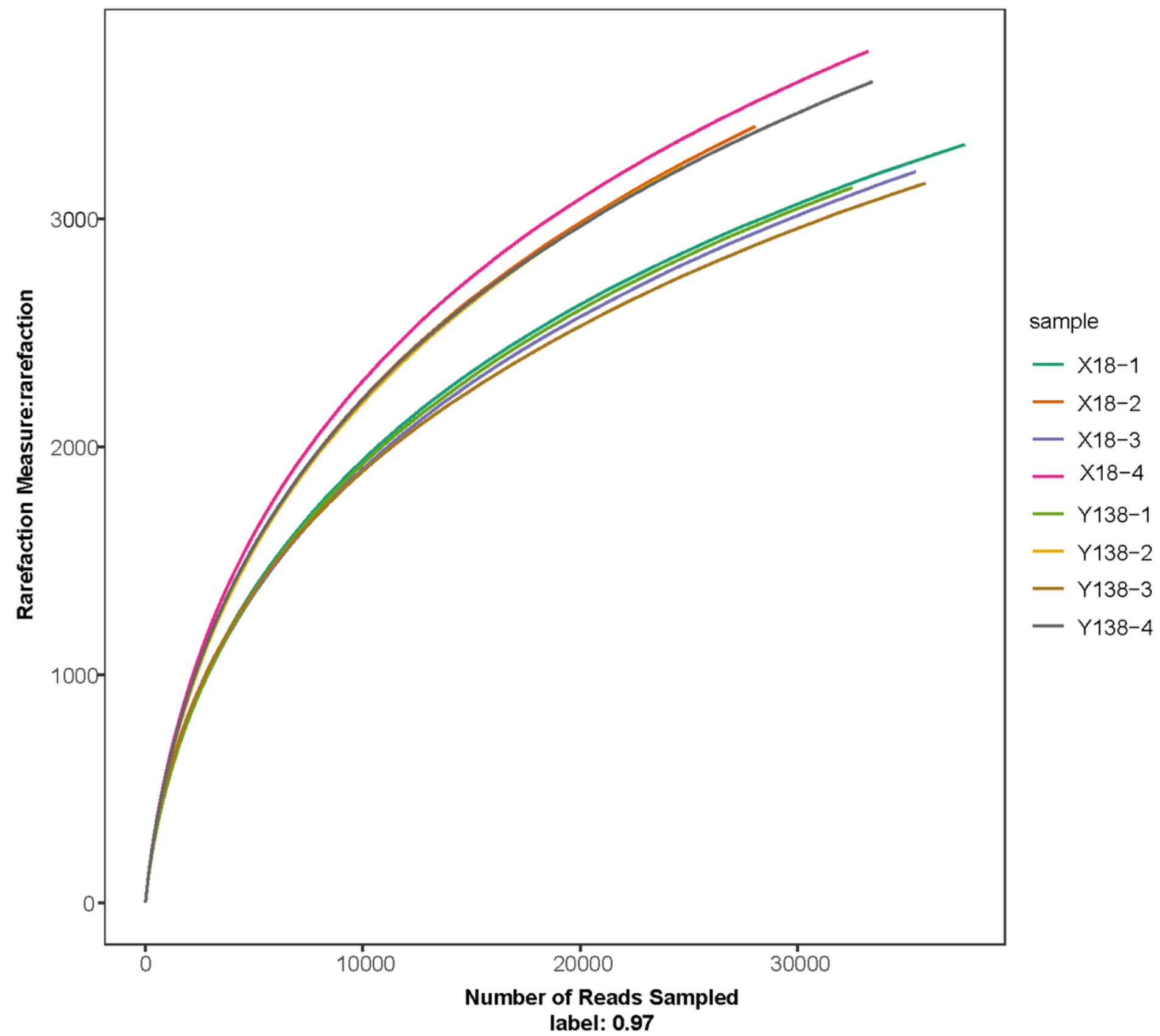

Figure 1

Rarefaction curves of all samples. 1 and 2 represent the early planting and pre-harvest samples in 2015; 3 and 4 represent the early planting and pre-harvest samples in 2016, respectively. The same as following. 


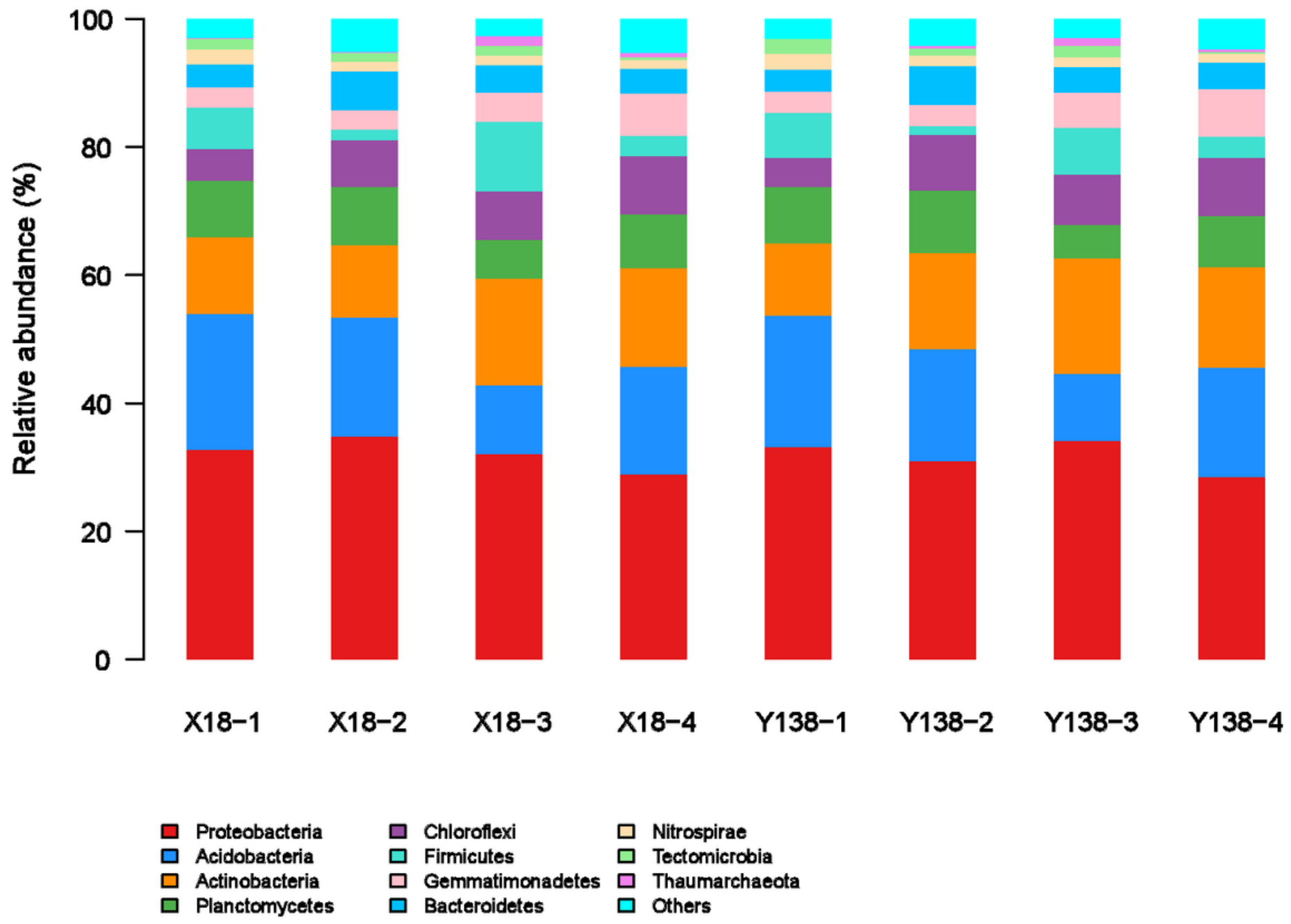

Figure 2

Relative abundance of rhizospheric soil bacterial phyla. 


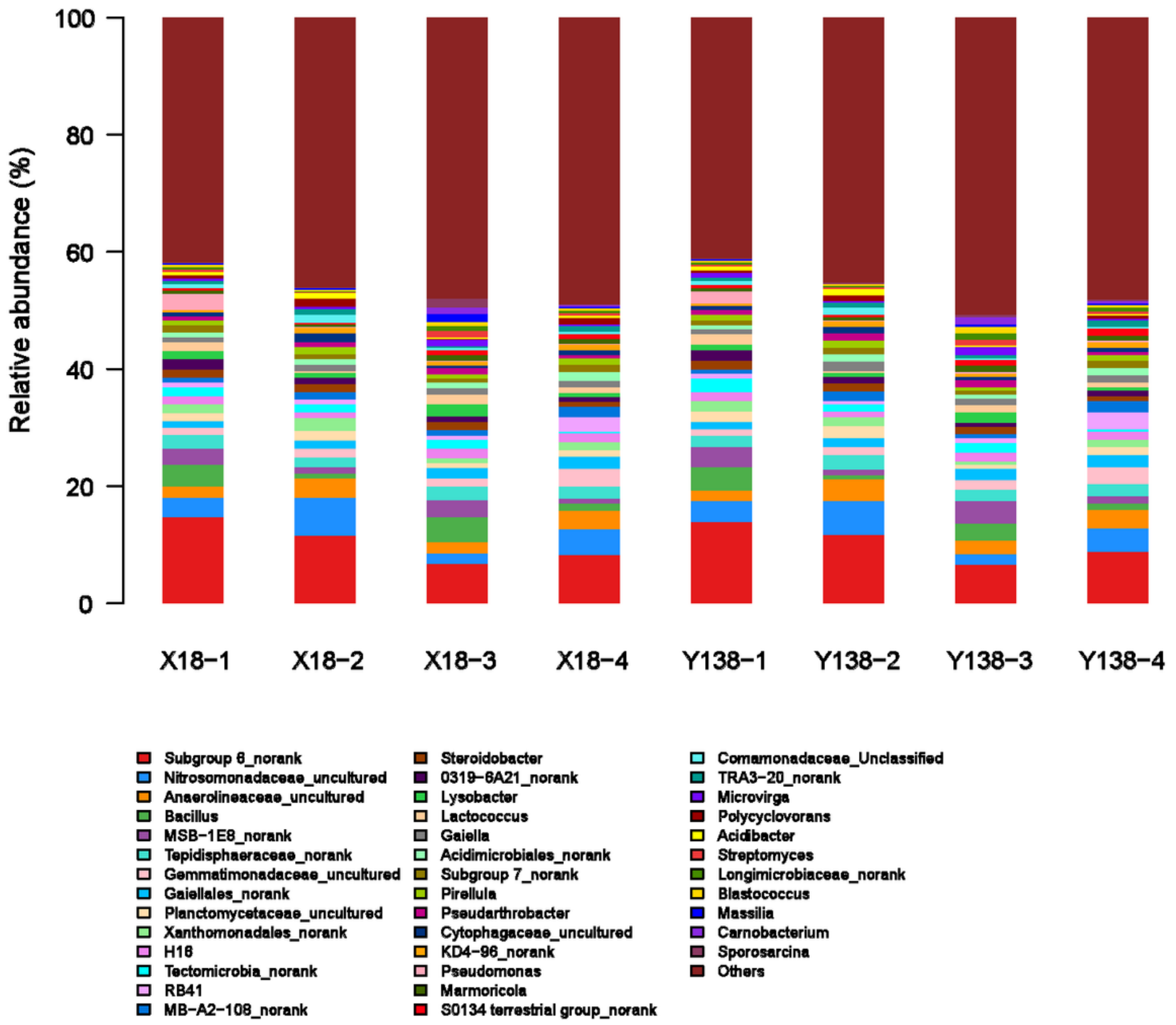

Figure 3

Relative abundance of rhizospheric soil bacterial genera. 


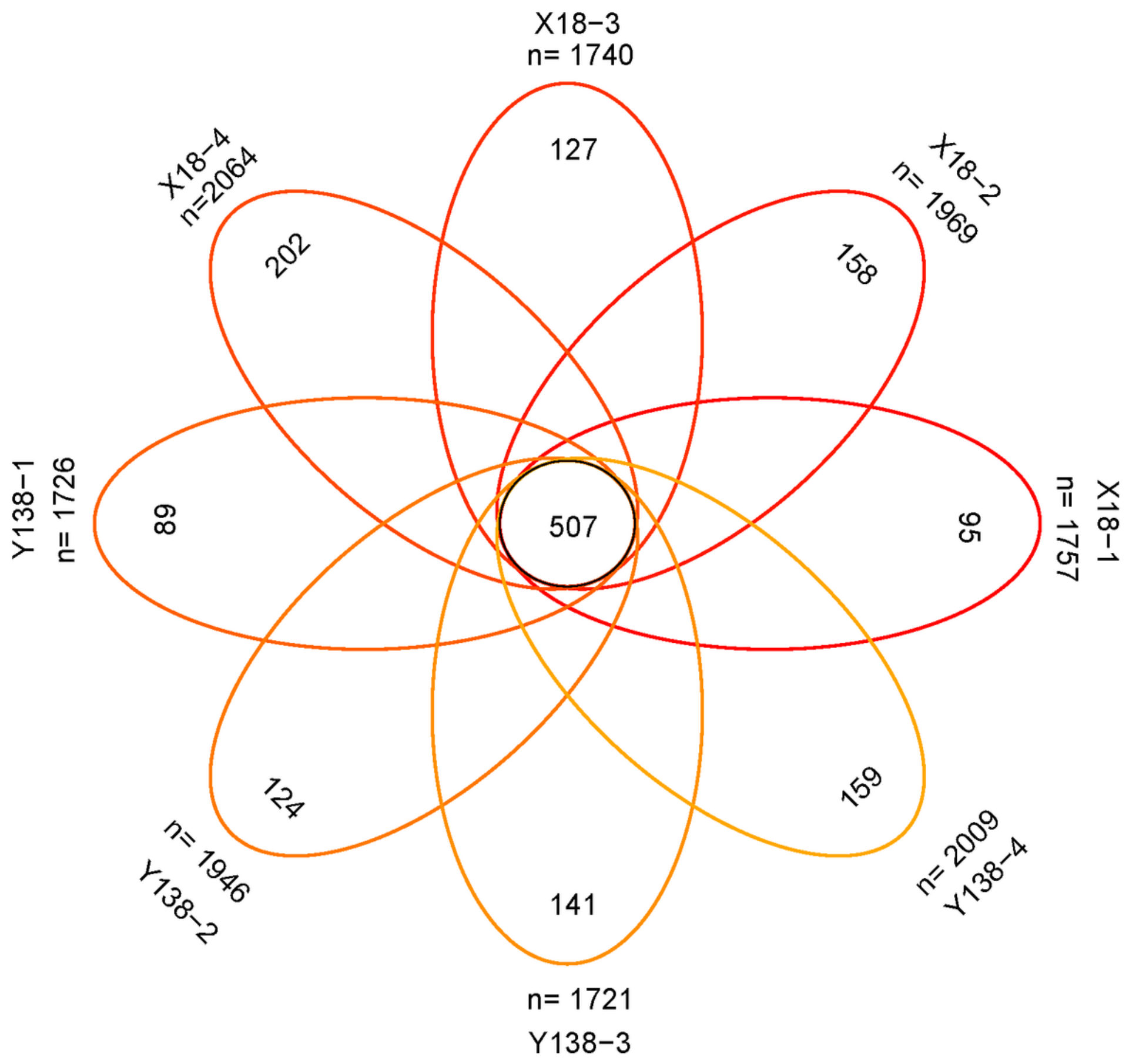

Figure 4

Number of common and unique OTUs based on Venn analysis. 


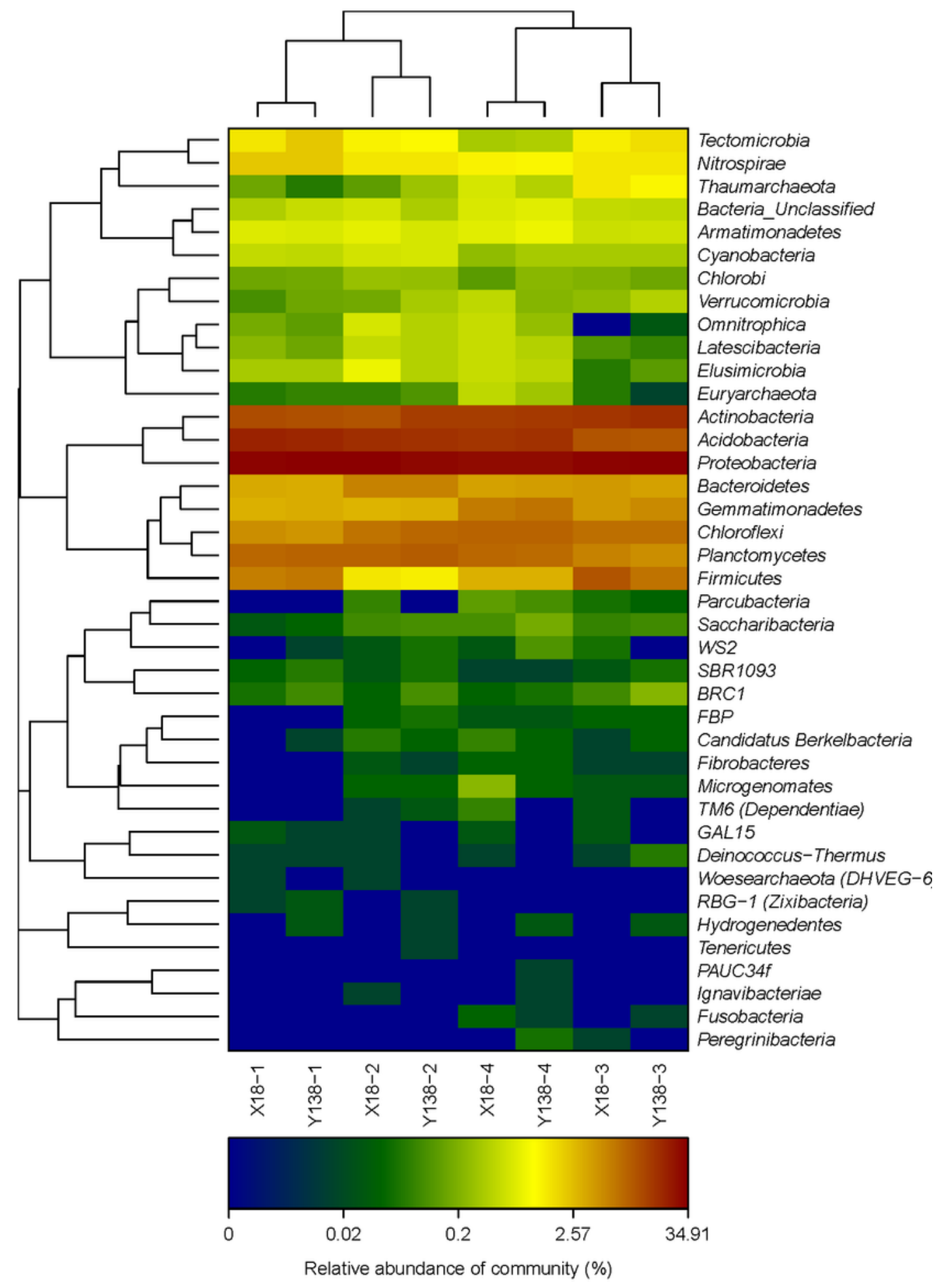

Figure 5

Microbial community heatmap and cluster analysis of the bacterial phyla. 


\section{PCA}

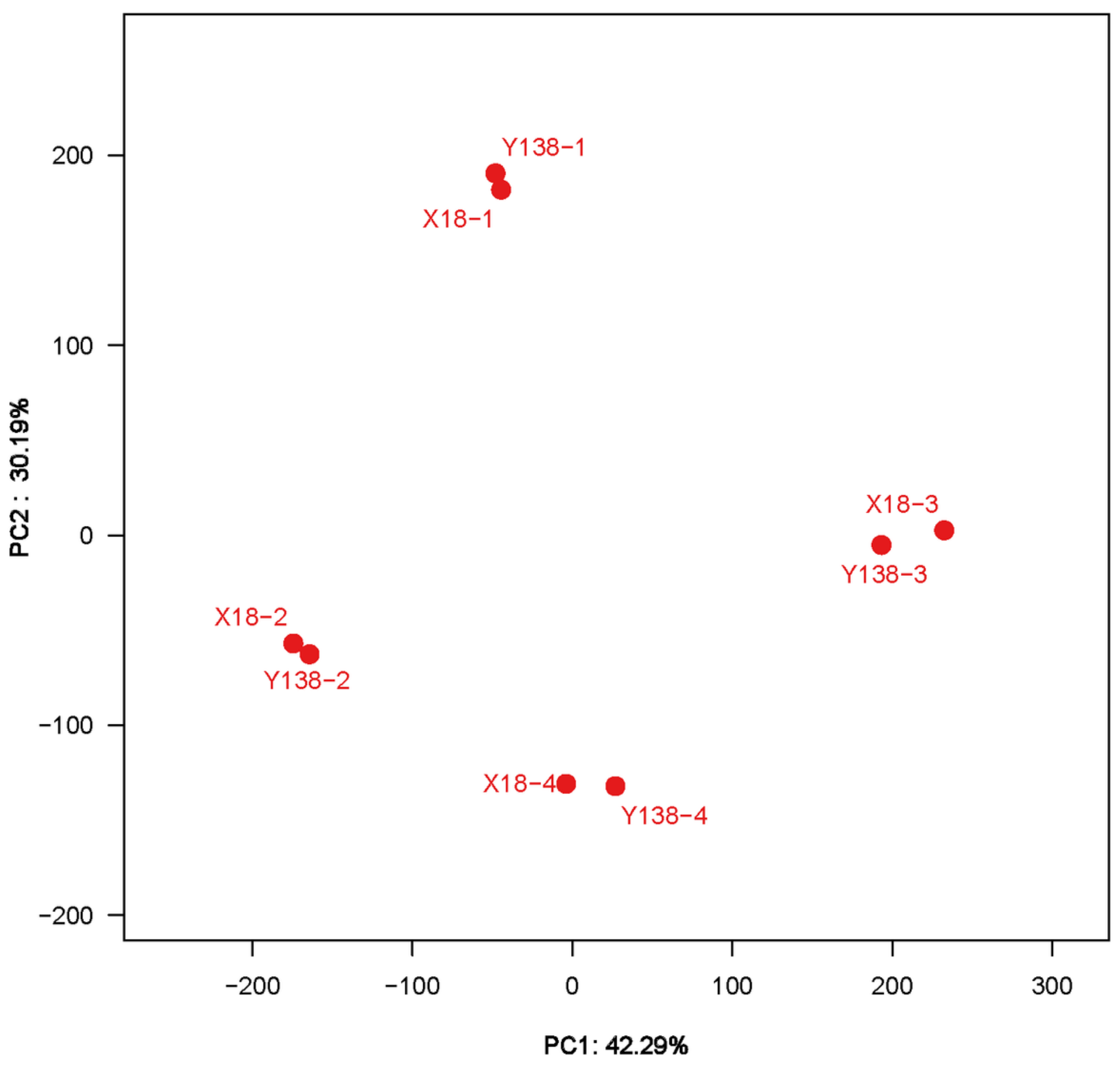

Figure 6

Principal component analysis (PCA) of OTUs. 
RDA

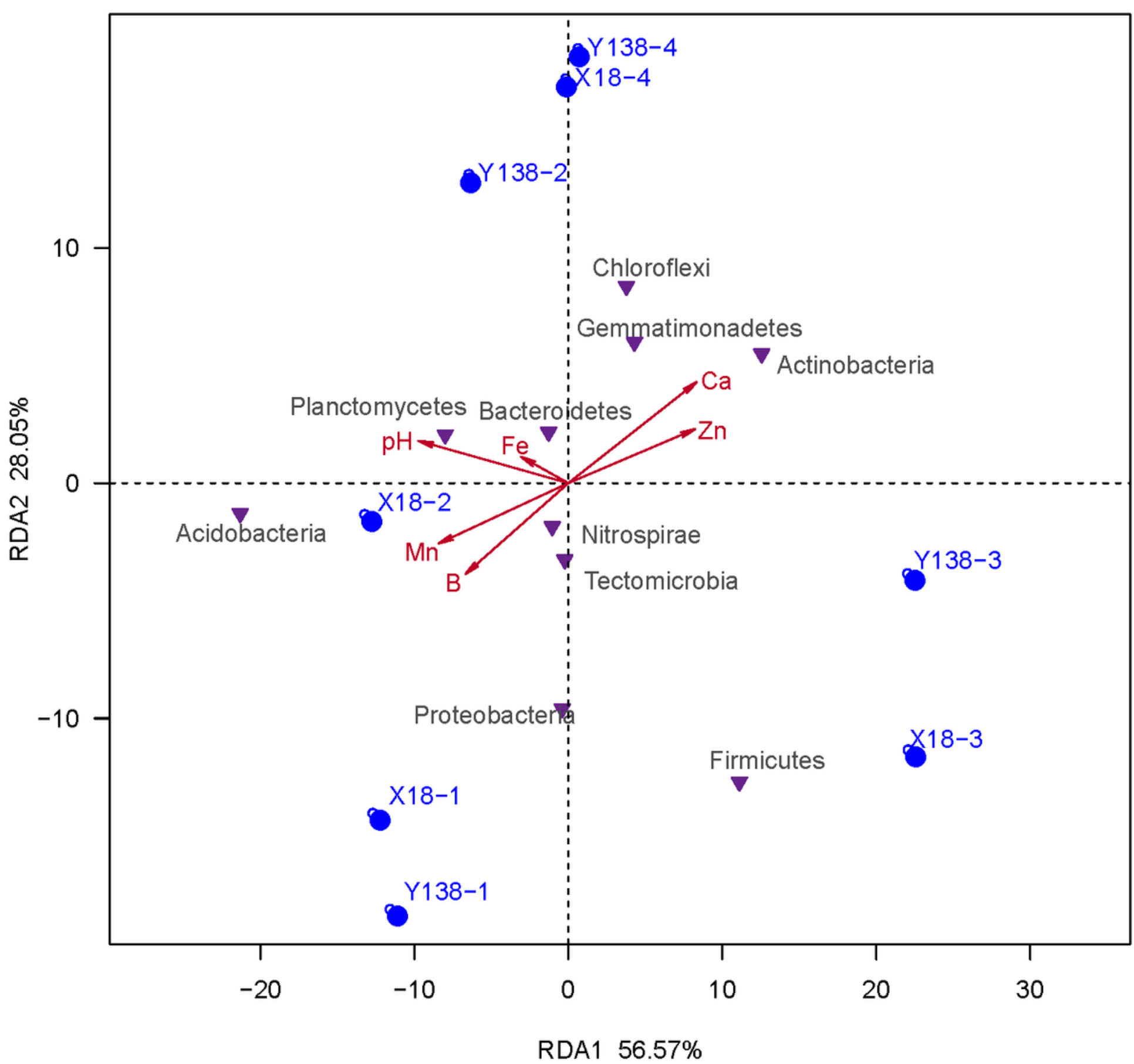

Figure 7

Redundancy analysis of the 10 dominant bacterial phyla and soil physicochemical properties. Ca: available calcium; B: available boron; Fe: available iron; Mn: available manganese; Zn: available zinc. The same as following. 


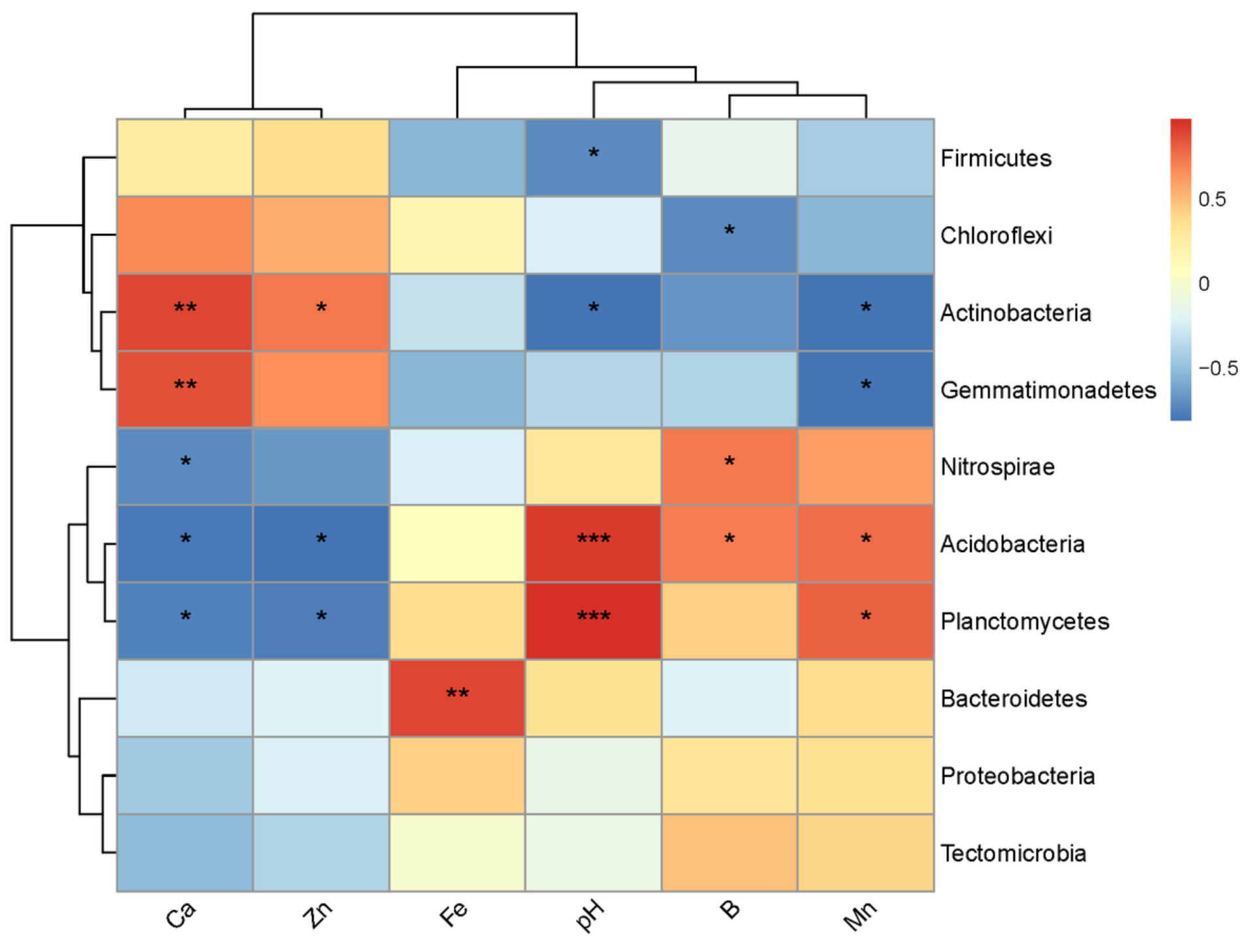

Figure 8

Correlations between the 10 dominant bacterial phyla and soil properties. ${ }^{*}, \mathrm{P}<0.05$; $* \star, P<0.01$; $* \star \star$, $\mathrm{P}<0.001$. 